\title{
Reports of violence against women in different life cycles
}

\author{
Maísa Tavares de Souza Leite ${ }^{1}$ \\ Maria Fernanda Santos Figueiredo ${ }^{2}$ \\ Orlene Veloso Dias $^{3}$ \\ Maria Aparecida Vieira ${ }^{4}$ \\ Luís Paulo Souza e Souza ${ }^{5}$ \\ Danilo Cangussu Mendes ${ }^{6}$
}

Objective: to analyze the reports and factors associated with violence against women. Method: this was a cross-sectional, exploratory and analytical study with information about the cases of reported violence, extracted from the Civil Police Report Bulletin, in a mid-sized city in Minas Gerais, Brazil. Results: out of the 7,487 reports of violence against women, it was found that $44.6 \%$ of the cases were threats, $28.5 \%$ aggression, $25.1 \%$ bodily injury, $1.1 \%$ rape, and $0.7 \%$ some other type of injury. In the bivariate analysis, a higher number of cases $(p=0.000)$ committed by partners was evidenced, for all kinds of violence except for rape. Children, adolescents and adults experienced violence by partners, followed by family members. Regarding older women, violence was committed by family members. Conclusion: there is the need for programs to be established to prevent violence against women in various sectors of society, permeating the life cycle.

Descriptors: Women's Health; Violence Against Women; Epidemiology; Public Health.

\footnotetext{
${ }^{1}$ PhD, Full Professor, Centro de Ciências Biológicas e da Saúde, Universidade Estadual de Montes Claros, Montes Claros, MG, Brazil. 2 Doctoral student and Profesor, Centro de Ciências Biológicas e da Saúde, Universidade Estadual de Montes Claros, Montes Claros, MG, Brazil. ${ }^{3}$ Doctoral student and Full Professor, Centro de Ciências Biológicas e da Saúde, Universidade Estadual de Montes Claros, Montes Claros, MG, Brazil. ${ }^{4}$ Doctoral student, Escola Paulista de Enfermagem, Universidade Federal de São Paulo, São Paulo, SP, Brazil. Full Professor, Centro de Ciências Biológicas e da Saúde, Universidade Estadual de Montes Claros, Montes Claros, MG, Brazil.

${ }^{5}$ Master's student, Escola de Enfermagem, Universidade Federal de Minas Gerais, Belo Horizonte, MG, Brazil.

${ }^{6}$ PhD, Full Professor, Departamento de Odontologia, Centro de Ciências Biológicas e da Saúde, Universidade Estadual de Montes Claros, Montes Claros, MG, Brazil.
}

Corresponding Author:

Luís Paulo Souza e Souza

Rua Doze, 27

Bairro: Santo Antônio

CEP: 39402-285, Montes Claros, MG, Brasil

E-mail: luis.pauloss@hotmail.com
Copyright (c) 2014 Revista Latino-Americana de Enfermagem This is an Open Access article distributed under the terms of the Creative Commons Attribution Non-Commercial License (CC BY-NC).

This license lets others distribute, remix, tweak, and build upon your work non-commercially, and although their new works must also acknowledge you and be non-commercial, they don't have to license their derivative works on the same terms. 


\section{Introduction}

Violence is a historical, social and health issue of great magnitude and worldwide transcendence, with macrostructural roots. It is diluted in society, polymorphous, multifaceted and presents several manifestations that interlock, interact, feed back and become stronger. It owns forms of conjunct expressions present in everyday interpersonal relationships ${ }^{(1-2)}$. Studies highlight the consequences of violence resulting from injuries and trauma, directly and indirectly, generated by the violent act, that are perceived by the economic costs of medical assistance, the judicial and penal system, in addition to the social costs of reduced productivity ${ }^{(1-4)}$.

Among the various forms of violence, domestic aggression against women is a serious public health issue(1), having been summarized in the sociological category known as gender from the twentieth century(3), understood as a set of social, cultural, political, psychological, legal and economical characteristics attributed to people, as well as to the health-disease process, differentiated according to gender ${ }^{(3,5)}$. Thereby, this category includes types of violence resulting from the unequal relationships between the genders $^{(3)}$.

Recent national and international studies show the high prevalence of at least one form of violence against women. In rural Nepal, more than half (51.9\%) of married women between 15-24 years of age have experienced some type of partner violence ${ }^{(6)}$; in Karachi (Pakistan), the self-reported prevalence among women aged 25 to 60 years was $56.3 \%{ }^{(7)}$. In India, the prevalence was $56 \%{ }^{(8)}$, and in Spain, $24.8 \%$ of women reported having been abused by their partner at least once in life. There are variations in prevalence according to the region. The highest percentages have been recorded in Ceuta and Melilla (40.2\%) and the Balearic Islands (32.5\%). The lowest percentages registered have occurred in Cantabria $(18 \%)^{(9)}$ and in the city of Celaya - Mexico(10) $(8.1 \%)$.

In Brazil, a cross-sectional study conducted in the city of Feira de Santana (BA) showed that, among individuals who experienced violence, $76.3 \%$ of the reports were related to women ${ }^{(11)}$. In research conducted with users of the National Health Service (SUS) in the city of São Paulo, $15-49$ years of age, the prevalence was $59.8 \%{ }^{(12)}$.

Some factors have been associated with violence against women by an intimate partner, such as: alcohol abuse, cohabitation, young age, attitudes supportive of wife beating, having suffered childhood abuse, and experiencing other forms of violence in adulthood(13).
The effects of domestic violence can have significant impact on women's lives ${ }^{(14-15)}$ and society, which demonstrates the scope and magnitude of the problem ${ }^{(15)}$. However, there are difficulties in preventing its occurrence, or act of coping, due to: cultural barriers, educational factors, and lack of educational and professional services to meet the cases of domestic violence ${ }^{(16)}$. Thereby, state intervention in the execution of public policies is required to produce affirmative actions that are actually effective in reducing gender violence(14-15).

The approach of gender violence in health services demand practices congruent with this perspective ${ }^{(17)}$, in order to give visibility to violence, to incorporate the gender perspective in the actions and possibilities of active listening.

Violence is considered a "silent epidemic" and the few studies result from concrete actions, or are associated with them, related to their alleviation or reduction. Thereby, the situation is aggravated even further when the object of analysis is the city space, since most investigations refer to macro-regional areas of the country, leaving undiagnosed the peculiarities and extent of violence against woman in the local space.

Thereby, this study aimed to analyze the reports and factors associated with violence against women in a mid-sized city of the State of Minas Gerais, Brazil.

\section{Method}

This was a cross-sectional, exploratory and analytical study. Primary data containing information referring to cases of violence against women registered from January to December of 2010 were extracted from the Civil Police Report Bulletins. These data were collected at the website armazemsids.mg.gov.br "Bussiness Object", of the 11th Civil Police Department of Montes Claros, an organ of the Civil Police at the State of Minas Gerais, Brazil, by institutional workers authorized to perform this collection, so that the identity of offenders and victims was preserved, and so that the authors did not have access to the names of the individuals.

The explanatory variables about the types of violence against women contained in Report Bulletins collected for analysis were: Aggression, Threat, Rape, Injury and Bodily Injury. The concepts used in this study for these variables were extracted from the Brazilian Penal Code ${ }^{(18)}$, except for aggression, which did not appear in the code.

- Aggression: Attack to physical integrity or act of hostility and provocation, which aims to cause harm to the person to whom it is addressed ${ }^{(19)}$. 
- Threat: "Threatening someone, by words, writing or gesture, or any other symbolic medium, of causing him/ her unfair and severe harm (art.147)(18).

- Rape: "To constrain someone with violence or serious threat, into having carnal conjunction or to practice or allow lewd acts to be practiced with him/her" (Article 213) ${ }^{(18)}$.

- Injury: "To injury someone, offending his/her dignity and decorum" (art.140) ${ }^{(18)}$.

- Bodily Injury: "To offend the bodily integrity or health of others" (art. 129)(18).

In addition to the type of violence, information was collected regarding age of the victim (child /adolescent, adult and elderly), seasonality of violence occurrence (first, second, third or fourth quarter) and offender (partner, family, acquaintance, stranger, other). For the latter variable, the categories were grouped according to the records of the Civil Police. Partner was considered: the spouse, ex-spouse, extramarital or intimate relationship. Included in the family category were: grandparents/great grandparents, grandson/greatgrandson, son/stepson, brother, parents/legal guardians or other unspecified family relationship. Included within the acquaintance option were: friends, domestic relationship/cohabitation, coworker/superior, business partner/building partner or neighbor. The category "stranger" contained the cases without any kind of relationship, and the category "other" was considered the response option for cases that were not related to any category mentioned.

Data were tabulated and analyzed using the Statistical Package for the Social Sciences $\left(\right.$ SPSS $^{\circledR}$ ) software, version 18.0 for Windows $^{\circledR}$. Initially, a descriptive analysis was performed, and subsequently, bivariate analysis was using the Chi-square test was applied. For this study, the significance level adopted was $5 \%(p<0.05)$, with a confidence interval of $95 \%$ (CI 95\%).

This study was approved by the General Delegate of Police - Regional Delegate of the Civil Police from the District of Montes Claros, by signing of the Institutional Form of Agreement for Participation in Research involving humans. and also by the Ethics Committee of Universidade Estadual Montes Claros, N. 185/2010.

\section{Results}

In 2010, 7487 cases of violence against women were registered by the Civil Police of Montes Claros using police reports from the Integrated Areas of Public Safety (IAPS), headquartered in this city.

Table 1 shows the descriptive data analysis. The 7487 cases of violence against women in the city of Montes Claros were characterized as follows: 3340 (44.6\%) threats, 2134 (28.5\%) aggression, 1877 (25.1\%) bodily injuries, $83(1.1 \%)$ rapes and $53(0.7 \%)$ as some other kind of injury. These acts of violence were committed throughout the life cycle, mostly against adult women $(80.9 \%)$, followed by children/adolescents $(14.5 \%)$ and older women (4.6\%). Regarding the period of the year, the records of violence against women occurred with a variation of $23.4 \%$ recorded in the first quarter to a maximum value of $28 \%$ in the fourth quarter.

Table 1 - Descriptive analysis of the cases of violence against women registered by the Civil Police in 2010. Montes Claros, Minas Gerais, Brazil

\begin{tabular}{|c|c|c|c|}
\hline Variable & Frequency & Percentage & Valid percentage \\
\hline \multicolumn{4}{|l|}{ Type of violence } \\
\hline Aggression & 2,134 & 28.5 & 28.5 \\
\hline Threat & 3,340 & 44.6 & 44.6 \\
\hline Rape & 83 & 1.1 & 1.1 \\
\hline Other injury & 53 & 0.7 & 0.7 \\
\hline Bodily injury & 1,877 & 25.1 & 25.1 \\
\hline Total & 7,487 & 100.0 & 100.0 \\
\hline \multicolumn{4}{|l|}{ Age } \\
\hline Child/Adolescent & 1,067 & 14.3 & 14.5 \\
\hline Adult & 5,968 & 79.7 & 80.9 \\
\hline Older woman & 341 & 4.6 & 4.6 \\
\hline Valid total & 7,376 & 98.5 & 100.0 \\
\hline No information (missing) & 111 & 1.5 & - \\
\hline Total & 7,487 & 100.0 & \\
\hline \multicolumn{4}{|l|}{ Period of the year } \\
\hline First Quarter & 1,750 & 23.4 & 23.4 \\
\hline Second Quarter & 1,821 & 24.3 & $\begin{array}{l}24.3 \\
\text { (continue...) }\end{array}$ \\
\hline
\end{tabular}


Table 1 - (continuation)

\begin{tabular}{|c|c|c|c|}
\hline Variable & Frequency & Percentage & Valid percentage \\
\hline Third Quarter & 1,820 & 24.3 & 24.3 \\
\hline Fourth Quarter & 2,096 & 28.0 & 28.0 \\
\hline Total & 7,487 & 100.0 & 100.0 \\
\hline \multicolumn{4}{|l|}{ Offender } \\
\hline Partner & 1,455 & 19.4 & 45.1 \\
\hline Family member & 641 & 8.6 & 19.9 \\
\hline Acquaintance & 439 & 5.9 & 13.6 \\
\hline Stranger & 377 & 5.0 & 11.7 \\
\hline Other & 315 & 4.2 & 9.8 \\
\hline Valid total & 3,227 & 43.1 & 100.0 \\
\hline No information (missing) & 4,260 & 56.9 & - \\
\hline Total & 7,487 & 100.0 & 100.0 \\
\hline
\end{tabular}

Source: Website armazemsids.mg.gov.br "Business Object", of the 11th Civil Police Department of Montes Claros, MG, Brazil

A high number of reported cases without proper identification of the offender was identified in the registration forms of the Civil Police ( $n=4260,56.9 \%$ of all cases of violence). Among the valid values for this variable, it was found that cases of violence were committed by someone close to the victim, $45.1 \%$ by a partner and $19.9 \%$ by a family member.

Regarding the distribution of cases of violence considering the offender and the age of the victims, it was observed in this study that, in the early stages of life (childhood and adolescence), there were similarities in the distribution of offenders according to the type of violence, except for aggression, which presented a much higher value for partner and family. When the cases in adulthood were analyzed, the pattern was peculiar, with an increase in violence caused by the partners of the

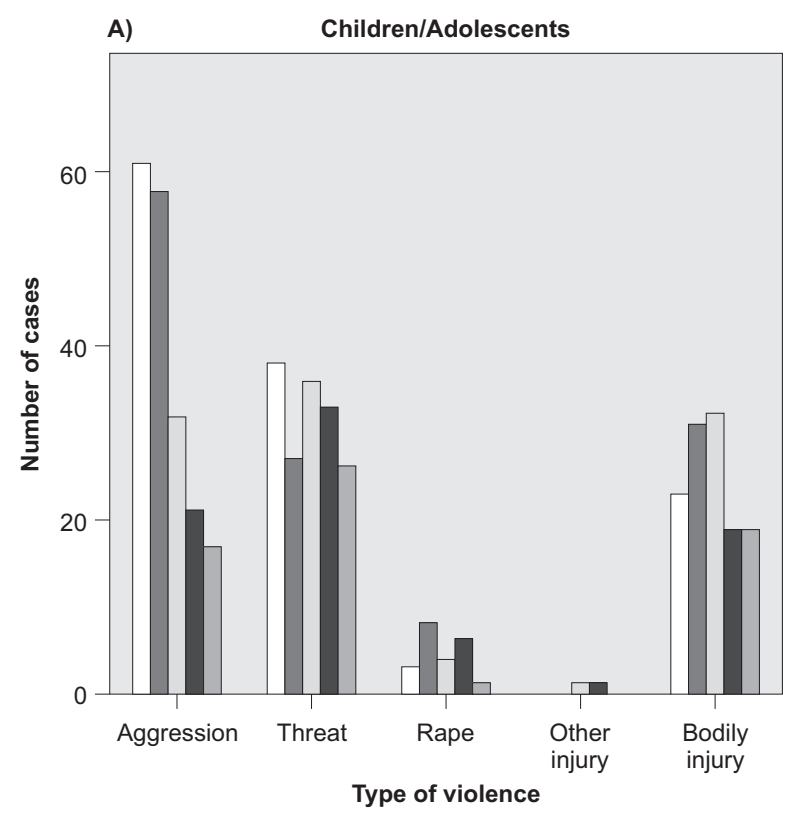

victims. Regarding the elderly, the family assumed the role of offender (Figure 1 ).

A bivariate analysis was performed using the variables "offender", "type of violence" and "age" to assess the statistical significance of the data (Table 2). The analysis showed a statistically significant association for all variables $(p=0.000)$, and the higher number of cases of violence was committed by partners for all kinds of violence, with the exception of rape (more common among family members and strangers) and injury (more common among acquaintances). The children/ adolescents were more likely to experience violence by a partner $(25.2 \%)$ followed by a family member (24.9\%), and in adulthood this difference was significant (50.8\% to $17.1 \%$ for partner and family). In older women, $52.1 \%$ of the cases of violence were committed by the victims' families.

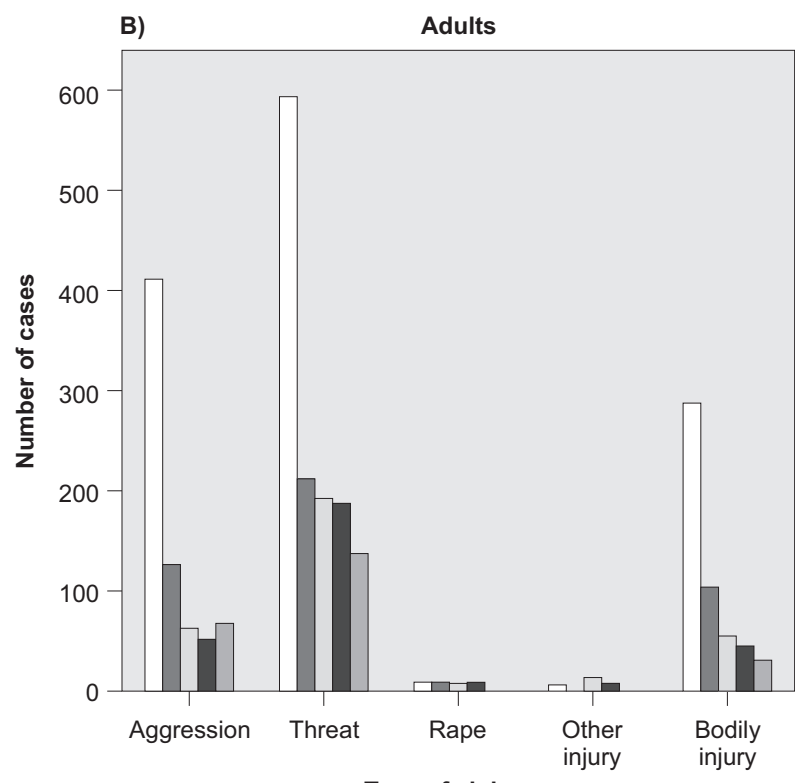

Type of violence

(The Figure 1 continue in the next page...) 

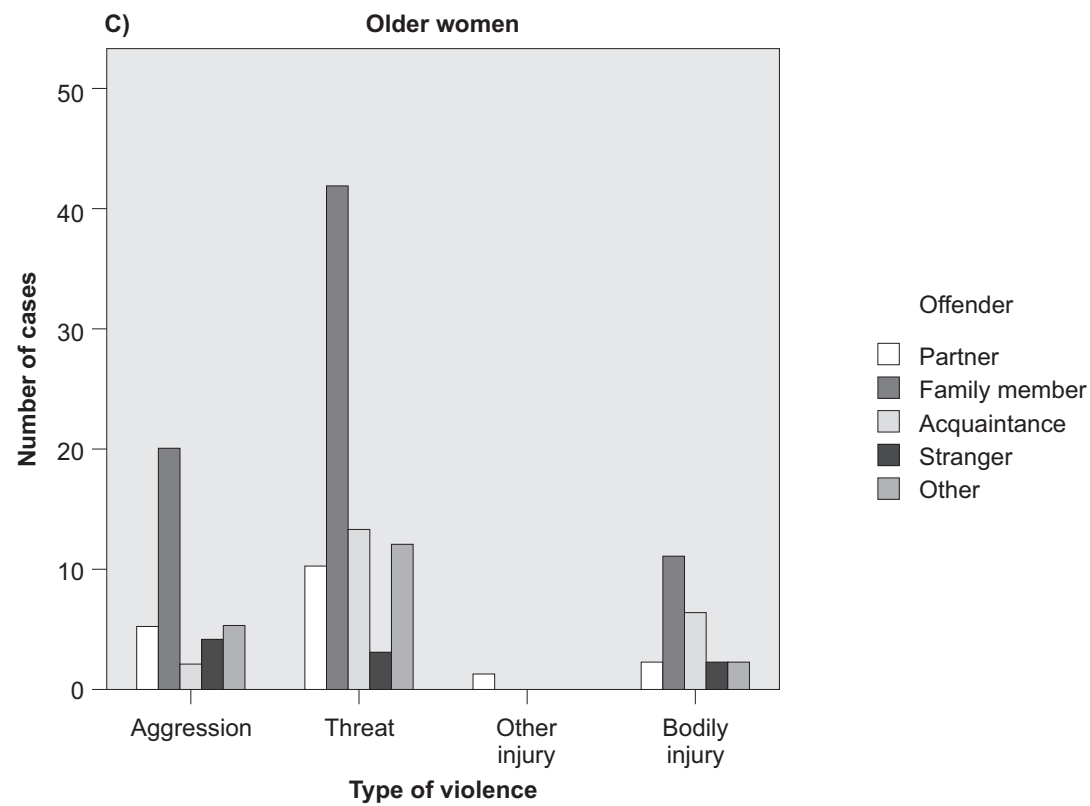

Figure 1 - Graphic pattern of distribution of the cases of violence, considering the offender, by age: A) children and adolescents; B) adult women; C) older women. Montes Claros, MG, Brazil, 2010

Table 2 - Bivariate analysis using offender, type of violence and age of the cases reported in 2010 by the Civil Police. Montes Claros, MG, Brazil

\begin{tabular}{|c|c|c|c|c|c|c|c|}
\hline \multirow{2}{*}{ Variable } & \multicolumn{6}{|c|}{ Offender } & \multirow{2}{*}{$\begin{array}{c}\mathbf{P} \\
\text { Value }\end{array}$} \\
\hline & Partner & Family member & Acquaintance & Stranger & Other & Total & \\
\hline Type of violence & & & & & & & $0.000^{*}$ \\
\hline Aggression & $480(51.4 \%)$ & $199(21.3 \%)$ & $91(9.8 \%)$ & $75(8 \%)$ & $88(9.4 \%)$ & $933(100 \%)$ & \\
\hline Threat & $647(41.3 \%)$ & $283(18.1 \%)$ & $240(15.3 \%)$ & $220(14 \%)$ & $177(11.3 \%)$ & $1,567(100 \%)$ & \\
\hline Rape & 07 (19.4\%) & $11(30.6 \%)$ & $06(16.7 \%)$ & $11(30.6 \%)$ & $01(2.8 \%)$ & $36(100 \%)$ & \\
\hline Other injury & $04(20 \%)$ & $01(5 \%)$ & $10(50 \%)$ & $05(25 \%)$ & $00(0 \%)$ & $20(100 \%)$ & \\
\hline Bodily injury & $317(47.2 \%)$ & 147 (21.9\%) & $92(13.7 \%)$ & $66(9.8 \%)$ & $49(7.3 \%)$ & $671(100 \%)$ & \\
\hline Total & $1,455(45.1 \%)$ & $641(19.9 \%)$ & $439(13.6 \%)$ & $377(11.7 \%)$ & $315(9.8 \%)$ & $3,227(100 \%)$ & \\
\hline Age & & & & & & & $0.000^{*}$ \\
\hline Child/Adolescent & $125(25.2 \%)$ & $124(24.9 \%)$ & $105(21.1 \%)$ & $80(16.1 \%)$ & $63(12.7 \%)$ & $497(100 \%)$ & \\
\hline Adult & $1,296(50.8 \%)$ & $436(17.1 \%)$ & $308(12.1 \%)$ & $283(11.1 \%)$ & $226(8.9 \%)$ & $2,549(100 \%)$ & \\
\hline Older woman & $18(12.9 \%)$ & $73(52.1 \%)$ & $21(15 \%)$ & $09(6.4 \%)$ & $19(13.6 \%)$ & $140(100 \%)$ & \\
\hline Total & $1,439(45.2 \%)$ & $633(19.9 \%)$ & $434(13.6 \%)$ & $372(11.7 \%)$ & $308(9.7 \%)$ & $3,186(100 \%)$ & \\
\hline
\end{tabular}

Source: Website armazemsids.mg.gov.br "Business Object", of the 11th Civil Police Department of Montes Claros, MG, Brazil

\section{Discussion}

Gender inequality has, as one of its extreme manifestations, violence against women as a result of the difference in power that translates into relationships of domination and power. Thereby, gender-based violence has been constituted as a social phenomenon which influences the way of life, illness and death of women ${ }^{(20)}$.

It was found in this study that, among forms of violence against women, threats were the most frequent $(44.6 \%)$. Similar results were observed in a study conducted in eastern India, where psychological violence against women reached a percentage of $52 \%{ }^{(8)}$ and in another study conducted in Nova Friburgo, Rio de Janeiro - Brazil, where $20.6 \%$ of cases related to such forms of violence were found(21). In rural Nepal, sexual violence has the highest rates, totaling $46.2 \%{ }^{(6)}$.

The analyses of this study were statistically significant for all variables $(p=0.000)$, and a higher number of cases of violence was committed by the partner for all kinds of violence, with the exception of rape, which was more common among family members and strangers, and injury, in which acquaintances were the most prevalent offenders. 
Authors report that violence against women is mainly expressed through physical, sexual and psychological violence, affecting a woman's biopsychosocial integrity. Most of the acts suffered by women happen within the family, by intimates, particularly in the domestic sphere. Women are at greater risk of violence in relationships with family members and friends than with strangers and, in the majority of cases, the offender was their spouse or partner(22).

In the present study, the higher incidence of violence among adult women (80.9\%) is in line with that seen in the cases of violence attended in a Women's Division in the metropolitan region of Porto Alegre, Rio Grande do Sul-Brazil, with ages between 24 and 45 years accounting for $59 \%$ of cases $^{(23)}$. Similar results were also found in a study with women in Feira de Santana, Bahia - Brazil(11).

This phenomenon has also been observed internationally. A study performed in eastern India showed that the prevalence of all forms of violence increased with age ${ }^{(8)}$ and in Spain, the average age of onset of violence against women committed by their partners was 25 years old(9).

A multicenter study conducted in Bangladesh, Brazil, Ethiopia, Japan, Namibia, Peru, Tanzania, Samoa, Serbia and Montenegro, Thailand, showed that women aged 15 to 49 years were significantly associated with increased risk of intimate partner violence ${ }^{(13)}$. One of the explanations related to this fact is that, in adulthood, the woman is in a period of higher sexual and reproductive $\operatorname{activity}^{(23)}$. However, one may wonder whether the violent incidents with children and adolescents have not remained hidden, since they depend on someone else to make the report, which is a proper attitude, considering that the protection of these individuals depends on the knowledge of violence by the competent individuals and organizations ${ }^{(24)}$. The frequent omission of health professionals reporting the cases is noteworthy ${ }^{(4)}$.

The relationship between higher levels of violence and the place of its occurrence was found in a study conducted in the city of João Pessoa, Paraíba, Brazil, which identified differences related to risk of incidence of violence between neighborhoods ${ }^{(3)}$. This fact can be understood by considering that violence is linked to the socioeconomic conditions of a population, to the issues of lifestyle and characteristics of the territory. Noteworthy is the use of geoprocessing tools for the study and control of urban violence, in order to aid the process of decision making of managers in the construction of public policies compatible with reality in order to confront this situation(3).
In this investigation, when the offender was identified, the intimate partner of the woman appeared with the highest prevalence (45.1\%), higher than that found in population-based study conducted with women in the city of São Paulo and 15 municipalities in Pernambuco, Brazil(25).

Intimate partners were also the main perpetrators of violence against women internationally, as observed in eastern India(8) and Spain(9). A study in rural Nepal showed that more than half $(51.9 \%)$ of young married women reported having experienced some form of violence by their husbands ${ }^{(6)}$.

In the multicenter study cited before, it was identified that women who lived with a partner without being formally married to him had an increased risk for intimate partner violence. In contrast, women who were not living with their partners had lower risks. The research also showed that most new relationships were at increased risk for intimate partner violence(13).

The action of a family member in the occurrence of violence against women was also significant (19.9\%) in the present study, coming right after the intimate partner, as verified in a study conducted in Spain(9).

Thereby, for women victims of domestic violence, the home, considered before as a safe place, began to represent a risk, since the offender is inside(23). From this perspective, violence against women requires a different approach when caused by an offender who shares intimate relations with the victim, which is still permeated by historical and cultural issues legitimized and cultivated in the male dominance in social relations between genders ${ }^{(3)}$.

It must be considered that in some cases, women are unable to escape from this situation of violence because they lack access to the means and resources needed to eliminate their dependence on the offender. These women require psychological assistance, social support, legal advice, housing, daycare, school, and/or a job to acquire financial autonomy and healthcare(26). This situation demonstrates the importance of comprehensive, integrated and effective cross-sector network in the health of women, which includes homeshelters, centers and rehabilitation, defenders and Women Police Stations, Policy Secretariat for Women, Health and Planning Department Secretariat, so that the integrality and effectiveness of care for female victims of violence can be ensured ${ }^{(3-4)}$.

The essential role of the Family Health Strategy (FHS) in recognizing cases of gender-related violence is also noteworthy. The cases are recognized through a 
translation of a demand for other health care and in coping with health needs of women who experience it, facilitated by the bond prompted by the logic of its attention ${ }^{(5)}$ and its assignment to promote intersectorality.

Therefore, it is essential that professionals working in services addressing coping with violence are able to attend female victims of violence ${ }^{(27-28)}$, with integrated, interdisciplinary interventions with a broader approach(16-17), through an emancipatory praxis, allowing these women to face and overcome this reality ${ }^{(5,16)}$. Furthermore, it is essential that these professionals help uncover this issue, through notification of the cases, and other forms of reporting and monitoring to reduce the invisibility of violence as a health issue ${ }^{(5,17)}$ and break the stigma with which it is associated(17).

\section{Conclusion}

The results of this study confirm the need for programs to prevent violence against women to be structured in universities, schools, institutions of Primary Health Care, health facilities and social movements, in order for change to occur in the context described. Also, the development of educational practices focused on redefining the roles of women in family and society should be advocated.

Therefore, the reduction of violence against women requires intersectoral commitment by governments and society in order to establish a culture of peace and humane care for all age groups, especially children and elderly, who are more vulnerable.

\section{References}

1. Ministério da Saúde (BR). Secretaria de Vigilância em Saúde. Impacto da violência na saúde dos brasileiros. Brasília (DF): Ministério da Saúde; 2005.

2. Reichenheim ME, Souza ER, Moraes CL, Mello Jorge $\mathrm{MH}$, Silva CM, Souza Minayo MC. Violence and injuries in Brazil: the effect, progress made, and challenges ahead. Lancet. 2011;377:1962-75.

3. Lucena KDT, Silva ATMC, Moraes RM, Silva CC, Bezerra IMP. Análise espacial da violência doméstica contra a mulher entre os anos de 2002 e 2005 em João Pessoa, Paraíba, Brasil. Cad Saúde Pública. 2012;28(6):111121. doi: $10.1590 / S 0102-311 X 2012000600010$

4. Oliveira MT, Samico I, Ishigami ABM, Nascimento RMM. Violência intrafamiliar: a experiência dos profissionais de saúde nas Unidades de Saúde da Família de São Joaquim do Monte, Pernambuco. Rev Bras Epidemiol. 2012;15(1):16678. doi: 10.1590/S1415-790X2012000100015

5. Guedes RN, Fonseca RMGS, Egry EY. Limites e possibilidades avaliativas da estratégia saúde da família para a violência de gênero. Rev Esc Enferm USP. [Internet] 2013. [acesso 23 ago 2013]; 47(2):304-11. Disponível em: http://www.scielo.br/scielo.php?script=sci_arttext\& pid $=$ S0080 $-62342013000200005 \&$ Ing $=$ pt

6. Lamichhane P, Puri M, Tamang J, Dulal B. Women's Status and Violence against Young Married Women in Rural Nepal. BMC Women's Health. [Internet]. 2011. [acesso $18 \mathrm{dez} 2012] ; 11(19): 1-31$. Disponível em: http://www.biomedcentral.com/1472-6874/11/19

7. Ali TS, Asad N, Mogren I, Krantz G. Intimate partner violence in urban Pakistan: prevalence, frequency, and risk factors Int J Womens Health. [Internet]. 2011. [acesso 18 dez 2012];3:105-15. Disponível em: http:// www.ncbi.nlm.nih.gov/pmc/articles/PMC3089428/

8. Babu BV, Kar SK. Domestic violence against women in eastern India: a population-based study on prevalence and related issues. BMC Public Health. [Internet]. 2009. [acesso 15 dez 2012]; 9(129):1-18. Disponível em: http://www.biomedcentral.com/1471-2458/9/129

9. Ruiz-Pérez I, Plazaola-Castaño J, Vives-Cases C, Montero-Piñar MI, Escribã-Agüir $\mathrm{V}$, Jiménez-Gutiérrez $E$, et al. Variabilidad geográfica de la violencia contra las mujeres en España. Gac Sanit. [Internet]. 2010 [acesso 16 dez 2012];24:128-35. Disponível em: http:// www.ucm.es/info/seas/comision/tep/mt/Variabilidad_ geografica_de_la_violencia_contra_las_mujeres $\% 20$ en_Espana.pdf

10. Herrera Paredes, JM e Ventura, CAA. Alcohol consumption and domestic violence against women: a study with university students from Mexico. Rev. LatinoAm. Enfermagem. 2010;18(spe):557-64.

11. Rocha SV, Almeida MMG, Araújo TM. Violence against women among urban area residents in Feira de Santana, Bahia, Brazil. Trends Psychiatry Psychother. [Internet]. 2011. [acesso $18 \mathrm{dez} 2012$ ];33(3):164-8. Disponível em: http://www.scielo.br/scielo.php?pid=S2237-60892011 000300006\&script $=$ sci_arttext

12. Barros C, Schraiber LB, França-Junior I. Associação entre violência por parceiro íntimo contra a mulher e infecção por HIV. Rev Saúde Pública. 2011;45(2):36572. doi: 10.1590/S0034-89102011005000008

13. Abramsky T, Watts $\mathrm{CH}$, Garcia-Moreno C, Devries $K$, Kiss L, Ellsberg $M$, et al. What factors are associated with recent intimate partner violence? findings from the WHO multi-country study on women's health and domestic violence. BMC Public Health. [Internet]. 2011. [acesso $14 \mathrm{dez} 2012] ; 11(109): 1-29$. Disponível em: http://www.biomedcentral.com/1471-2458/11/109

14. Carneiro AA, Fraga CK. A Lei Maria da Penha e a proteção legal à mulher vítima em São Borja no Rio Grande do Sul: da violência denunciada à violência silenciada. Serv Soc Soc [Internet]. 2012. [acesso 13 dez 2012];1109:369-97. Disponível em: http://www. 
scielo.br/scielo.php?script=sci_arttext\&pid=S0101$66282012000200008 \&$ Ing $=$ en\&nrm $=$ iso

15. Azambuja MRD, Nogueira C. Qual a importância da violência contra mulheres na Revista Portuguesa de Saúde Pública?. Rev Port Saude Pub. [Internet]. 2010 [acesso 23 ago 2013]; 28(1):57-65. Disponível em: http:// www.scielo.gpeari.mctes.pt/scielo.php?script $=$ sci_artte $x$ t\&pid $=$ S0870-90252010000100007

16. Bernz IM, Coelho EBS, Lindner SR. Desafio da Violência Doméstica para profissionais da saúde: revisão da literatura. Saude \& Transf Soc. [Internet]. 2012 [acesso 23 ago 2013];3(3):105-11. Disponível em: http://www. incubadora.ufsc.br/index.php/saudeetransformacao/ article/view/1545/2157

17. Pedrosa CM, Spink MJP. A Violência Contra Mulher no cotidiano dos serviços de saúde: desafios para a formação médica. Saude Soc. $2011 ; 20(1): 124-35$. doi: 10.1590/S0104-12902011000100015

18. Decreto-Lei No 2848, de 7 de dezembro de 1940 (BR). Código Penal Brasil. Diário Oficial da União. [Internet]. 31 dez 1940. [acesso 18 dez 2012]. Disponível em: http://www.planalto.gov.br/ccivil_03/ decreto-lei/del2848compilado.htm

19. Biaggio AMB. Psicologia do desenvolvimento. Petrópolis: Vozes; 1996. 344 p.

20. Guedes RN, Silva ATMC, Fonseca RMGS. A violência de gênero e o processo saúde-doença das mulheres. Esc Anna Nery. 2009;13(3):625-31. doi: 10.1590/S141481452009000300024

21. Pazo CG, Aguiar AC. Sentidos da violência conjugal: análise do banco de dados de um serviço telefônico anônimo. Physis. [Internet]. 2012 [acesso 13 dez 2012]; 22(1): 253-73. Disponível em: http://www.scielo.br/ pdf/physis/v22n1/v22n1a14.pdf
22. Lettiere A, Nakano AMS, Bittar DB. Violência contra a mulher e suas implicações na saúde materno-infantil. Acta Paul Enferm. [Internet]. 2012. [acesso 13 dez 2012];25(4): 524-29. Disponível em: http://www.scielo.br/scielo. php?pid=S0103-21002012000400007\&script=sci_arttext 23. Gadoni-Costa LM, Zucatti APN, Dell'Aglio DD. Violência contra a mulher: levantamento dos casos atendidos no setor de psicologia de uma delegacia para a mulher. Estud Psicol. 2011;28(2):219-27.

24. Garbin CAS, Rovida TAS, Joaquim RC, Paula AM, Queiroz APDG. Violência denunciada: ocorrências de maus tratos contra crianças e adolescentes registradas em uma unidade policial. Rev Bras Enferm. 2011;64(4):665-70.

25. D'Oliveira AFPL, Schraiber LB, França-Junior I, Ludermir AB, Portella AP, Diniz CS, et al. Fatores associados à violência por parceiro íntimo em mulheres brasileiras. Rev Saúde Pública. [Internet]. 2009. [acesso 12 dez 2012]; 43(2):299-310. Disponível em: http://www.scielo.br/scielo.php?pid=S0034-89102011 000400013\&script $=$ sci_arttext

26. Silva MAI, Ferriani MGC. Domestic violence: from the visible to the invisible. Rev. Latino-Am. Enfermagem. 2007;15(2):275-81.

27. Souza JA, Almeida RA, Silva ATMC, Anjos UU. Modelo Baseado em Regras como Suporte à Atuação da Delegacia Especializada de Atendimento à Mulher no Encaminhamento de Mulheres em Situação de Violência Doméstica. Rev Bras Cienc Saúde. 2012;16(1):71-8. doi: 10.4034/RBCS.2012.16.01.11

28. Rodríguez-Borrego MA, Vaquero-Abellán M, Rosa LB. $A$ cross-sectional study of factors underlying the risk of female nurses' suffering abuse by their partners. Rev. Latino-Am. Enfermagem. 2012;20(1):11-8.

Received: Mar. 20th 2013 Accepted: Sept. 23 2013

\section{Erratum}

\section{Issue v22n1, page 85}

For

Luís Paulo Souza e Souza ${ }^{5}$

${ }_{5}^{5}$ Master's student, Centro de Ciências Biológicas e da Saúde, Universidade Estadual de Montes Claros, Montes Claros, MG, Brazil.

Read

Luís Paulo Souza e Souza ${ }^{5}$

${ }^{5}$ Master's student, Escola de Enfermagem, Universidade Federal de Minas Gerais, Belo Horizonte, MG, Brazil. 